\title{
The Dynamic of Online Friendship Quality: Exploration of Adolescence in Bandung
}

\author{
O Mardiawan', A F Helmi² \\ ${ }^{1,2}$ Universitas Gadjah Mada, ${ }^{1}$ Universitas Islam Bandung \\ ${ }^{1}$ okimardiawan@unisba.ac.id, ${ }^{2}$ avinpsi@ugm.ac.id
}

\begin{abstract}
This paper tries to raise the issue of the quality of online friendships in adolescents. Through this study, researchers try to explore the dynamics of online friendship quality in adolescents in Indonesia, especially in the area of Bandung, West Java. Participants in this study were 142 high school students drawn from six high schools in the city and district of Bandung. The exploration process uses a qualitative method through a focus group discussion technique, in which participants are asked to share their personal experiences in establishing good online friendship relationships and their experiences when experiencing bad online friendship relationships. Furthermore, participants were also asked to explain the factors that caused their online friendship relationships to be good or bad. Participant responses were analyzed using grounded theory. The results show that several features build the quality of friendship online such as companionship, sharing, mutual support, and voluntariness. There are several factors influence the quality of online friendship features, such as similarity, the motivation of affiliation, and personal attribute.
\end{abstract}

Keywords: Quality of friendship, Online, Adolescents

\section{INTRODUCTION}

The emergence of internet technology provides a fundamental change in human life, especially in matters of communication and social interaction. It is possible for a person to communicate with others without being bound by time and space [1], through the internet also humans can develop close relationships and interact with each other based on shared interests and mutual likes without being restricted by physical closeness as in offline relationships [2]. Internet technology, not only acts as a medium in the process of interaction, but also provides a new reality in communicating and interacting. Likewise, with the process of friendship interactions, now friendships can be made face-to-face and online. Even today, clear boundaries between online and offline contacts or friends no longer exist, especially in adolescents [3]. It is due to the connection between the reality experienced by individuals online and offline.

Developmental of friendships online, triggers researchers to examine online friendships. There are several differences of opinion among researchers, including in viewing the quality of online friendships. Some researchers claim that online friendship is of lower quality than faceto-face friendship; in fact, some of them state that online friendship is not genuine or unreal friendship [4], [5]. On the other hand, some researchers consider online friendships to be genuine friendships because online friendships allow individuals to overcome barriers that occur in offline interaction settings, express themselves and form meaningful intimate relationships 
with the people they meet online [6], offering the opportunity to socialize and express themselves without being affected by limitations, ethnicity and social status, and allows for someone who is not equal in offline to be able to interact equally on an online basis [7], and allows someone to share conversations and thoughts about their lives with others, because Aristotle's claim states that the best basis for friendship is life-sharing [8].

Also, several studies that tried to compare the quality of online and face-to-face friendships showed that the quality of face-to-face friendships had better friendships than online friends [9]-[12]. However, these studies also continue to show that either face-to-face friendship or quality online friendship continues to develop over time [9], [10], [13]-[15]. It also shows that the quality of online friendships can also be a quality, such as face-to-face friendships over time.

The difference of opinion regarding the quality of online friendship is inseparable from the development of the theory of computer-mediated communication (CMC). Walther divides the theory of computer-mediated communication into several groups, such as 'cues filtered out', 'cues to choose by', and 'cues filtered in' [16]. 'Cues filtered out' is a theory that focuses on the limitations of computer or online media in presenting cues in communication as a whole as in communication or face-to-face interaction, especially those related to non-verbal cues. It makes CMC always impersonal and lower quality than face-to-face communication. An example of this theory is the social presence theory developed by J Short, E. Williams, and B Christie in 1976 in a book entitled The Social Psychology of Telecommunications [14], [17], [18]. Furthermore, 'cues to choose by' is a theory which states that some messages can be conveyed effectively through one media compared to other media. It is evident in the media richness theory developed by Lengel and Daft [19], which states that in order to be able to understand and understand one another effectively, people need a rich communication channel. The more complex the communication task, the richer the channel is needed. Finally, a theory called cues filtered in theories [16] or theories of interpersonal adaptation [17], a theory that tries to see an individual as an active actor in directing the communication process and its relations, including when faced with obstacles or limitations in cues because individuals also have a relationship to relate, the ability to adapt and work to reduce uncertainty. 'Cues filtered in' view online communication can achieve the same quality as face-to-face communication; only it takes longer. It appears in the social information theory developed by Walther [14], [15].

Several studies attempt to identify features or dimensions of online friendship quality [20]-[22]. Some researchers try to identify features by trying to identify the presence and form of face-to-face friendship quality features on online friendships [20], modifying and adapting features and measurement scale of face-to-face friendship quality to measure the quality of online friendships [21], [23], and exploring features or dimensions of online friendship quality and scale-up [22]. Of the three things, the first and second ways are the most widely used methods in online friendship research, while the third way, which tries to explore online friendship qualitatively, is still not much, so researchers are interested in conducting exploratory research on online friendship quality.

In this study, researchers view that online friendship can have the same quality as faceto-face friendship, so researchers are also interested in knowing what the quality of friendship online is, what factors build and influence the quality of friendships online, and how they are dynamic.

\section{RESEARCH METHOD}

\subsection{Participant}


In this study, researchers involved 142 high school students from six high schools in the city and district of Bandung, consisting of 83 female students and 59 male students, with an age range of 14-17 years. Participants are high school students who actively interact with their friends online either through social media or instant messaging (IM). The selection of six high schools was carried out through a random process, whereas for the selection of participants through incidental sampling techniques in the six high schools.

\subsection{Procedur}

This research uses the qualitative phenomenology method. The data exploration process is carried out through a focus group discussion technique by asking two things. First, the researchers asked participants to share their experiences when experiencing good and bad friendship relationships online (e.g., "tell me your experiences when you had a good relationship with your friends online"). Furthermore, they were also asked to share the factors or reasons that made them experience the relationship of good and bad friendship (e.g., "why can you have a good friendship relationship online with her/him?"). Through this focus group discussion process, participants are asked to share their experiences freely, because the objective of this study is to explore the experiences and experiences of students when they are interacting with friends online.

Furthermore, the analytical method used by researchers is grounded theory, which is a method that aims to build theory from the data [24]. The steps taken are trying to understand transcripts by reading them, then do the open coding process, look for categorial, review category, and explain theme.

\section{RESULTS AND DISCUSSION}

\subsection{The Online Quality Dimensions of Friendship}

The results of the analysis of participant responses to questions related to participant experiences in making good and bad friendships online showed six main themes of online friendship quality, namely companionship, sharing, support, voluntariness, cautiousness and closeness

\section{Companionship}

Companionship is manifested in joint activities online, such as playing online games Together by forming a team or cooperation to win a match against the opposing team and discussing tips or strategies for winning the match in the personal chat or group chat they make. Alternatively, individuals can also discuss other interests, such as talking about things related to their idols, such as artists or football clubs. Companionship is also shown by meeting in person or doing activities together offline. For example, those who like K-pop and cover dance, besides discussing K-pop online, they also occasionally meet offline to meet and cover dance together, with the term "meet up" or "gathering."

"Kita teh masuk ke grup, jadi kan punya kesenengan yang sama kaya nih ada grup nih sama-sama seneng ini masuk deh, di invite kan akhirnya. Abis itu kaya ngomongin kesenengan itu terus kaya sampe yang temen-temen online nya itu ketemu di live nya. Faktornya ya karena kesenangan yang sama, kaya musik terus suka dance-dance gitu. Sampe akhirnya suka ketemu suka nge-cover bareng atau gimana gitu” $(A / 1 / M)$ 


\section{Sharing}

Sharing is the main activity in friendship interaction online because this activity is the process of delivering and exchanging information carried out by someone with their friends online. Information sharing behavior in online friendships varies, ranging from sharing information that is general to personal. The amount of information that is shared varies, some people share various things with their friends online, or otherwise limit the information shared with their online friends. In this study, several things are shared by teenagers with their friends online, such as information related to academics, insights, experiences, interests, experience, and personal. Thus, in this dimension, it can show many types of information shared with online friends and also the depth or personal level of the information.

"Saya punya temen online yang bener bener online sampai sekarang belum pernah ketemu. Kami ketemu di salah satu group line K-Pop gitu. Awalnya kan cuman say hi doang lama lama makin deket. Dia orang Surabaya, perempuan, dia kelas satu SMA, kami sering curhat masalah sekolah, curhat curhat masalah pendidikan, temen, lagi deket sama siapa....”. (N/1/S)

\section{Support}

The behavior of receiving and providing assistance online is one of the themes that emerge in online friendship interactions among adolescents in Bandung. The feeling of getting help can come in the form of giving or getting input or suggestions in solving problems they are facing, such as problems with schoolwork or personal problems. Also, assistance appears in the form of supports that they provide and get both in the form of encouragement or support when they are in poor condition. Mutual support is also felt by teenagers when they feel the mutual benefits from their online interaction processes, such as adding information and insight, helping to improve skills, helping achieve their goals or objectives.

"aku juga pernah ada di posisi mental breakdown gitu lah, dia yang ngebantu" $(\mathrm{N} / 20 / \mathrm{B})$

\section{Voluntariness}

This category illustrates that in establishing a friendship relationship online, teenagers have more flexible freedom in determining who will form friendship relationships, want to respond like what, and want to continue or not continue friendships with someone. It is evident in their freedom to decide "add friend" or "unfriend," "following," or "unfollowing," as well as communicating "synchronous" or "asynchronous." It means that online friendships are based more on the individual initiative or individual volunteerism in determining friendships. This dimension can affect an online friendship relationship that will continue or end. It is also influenced by whether voluntariness is reciprocal or only one-sided.

"Jadi kan kaya awalnya ngefollow di instagram terus minta nge follback, tah udah gitu lanjut ke wa, terus udah wa deket deket deket, terus ya gitu, udah gitu sering bales-bales sw gitu,...”. (L/1/C)

\section{Cautiousness}

The cautious dimension illustrates that in the online friendship process, adolescents have an awareness of the dangers that exist in cyberspace, such as the possibility of utilizing online 
friendships for fraud and crime. Therefore, raising caution in adolescents in sharing personal data, they tend to be more selective and vigilant in protecting their privacy, especially when interacting with friends they do not know well. Some teenagers tend not to like it very much when their online friends ask a lot about their privacy, especially if their friendship is not yet close.

"Abisnya aku mah kaya lebih jaga diri, terus gak mau terlalu terbuka sama orang yang belum terlalu dikenal. Paling temenan sama orang yang dari SD, SMP, SMA, paling kaya nanya nanya PR atau apa. Terus kaya suka curhat.. kaya lebih nyambung sama temen yang udah kita kenal.." (NN/20/B)

\section{Closeness}

Closeness is a category that illustrates the condition of a stronger attachment between individuals in their online friendship relationships, such as the presence of feelings close, understood, comfortable, and valued. Thus, interacting tends to be more flexible and open, like being able to joke, giving nicknames to friends without being offended, and so on.

"Kalau sudah merasa dekat gitu.Kalau masalah pribadi kalau yang offline ke online mah biasanya sering gitu, kaya... biasanya kan kalau hubungan udah deket biasanya kan suka punya nama panggilan tersendiri gitu, jadi pas kita online juga kita manggilnya diateh bukan dengan nama aslinya tapi dengan nama yang kita sering sebut juga gitu." (MT/20/S)

\subsection{Determinan Factors.}

\section{Similarity}

The similarity is the attribute possessed by adolescents that makes them decide to establish friendships and create a match between them when they interact. Based on the results of group discussions, there are several themes related to equality, such as having similar hobbies or activities, having similar interests or likes, having the same age, and having the same character.

"kalau misalnya yang online doang karna kita memiliki satu idola yang sama jadi bisa gampang gitu deketnya, jadi berawal dari pembahasan grup idola yang kita suka ntar jadi kehidupan pribadi gitu." (S/12/B)

\section{Motivation of affiliation}

This category illustrates related needs. Relationship needs emerge as the underlying theme of why teenagers make friends with friends online. This related need is illustrated by the desire to add and maintain existing friendships and the desire to recognize the traits or characters of his friends online

"Jadi kita dapat menambah kenalan-kenalan dan dapat mendapatkan banyak informasi gitu." (K/1/S).

"pertamanya tuh kita cuman basa-basi doang, kenalan gitu namanya siapa lebih tahu dirinya sama sifatnya gimana." (H/1/S)

\section{Personal Attribute}

Personal attributes are things or attributes that are inherent in individuals who become interaction partners in online that make teenagers interested or willing to establish good 
friendships with these individuals. There are several personal attributes of friends that become an attraction for a teenager to make good online friends, including physical attributes or in this case, the appearance of online, either through display in photos or through video calls. Also, personality attributes such as characters or attitudes displayed by someone during interaction affect the quality of online friendships, and finally are competency attributes in the form of skills or abilities that individuals show when related, such as the ability to help complete academic tasks, the ability to play games, or the ability to help solve problems.

"Ya orangnya.. ya biasalah asik, lucu, bikin nyaman.. gitu lah..sampe sekarang masih kenal dengan baik, masih suka komunikasi juga. Terus menurut aku cantik lah.. ya.. kayanya enak aja diajak temenan." (R/12/B)

"Karena dia skill-nya bagus, mainnya bagus, makanya saya follow, terus dia juga follow saya.” (T/1/C)

\section{Self Disclosure}

This theme illustrates the willingness of individuals or adolescents to present themselves as they are and provide or disclose information related to themselves to their friends. It can be seen from the willingness or unwillingness of adolescents to convey their identities to their friends online. This theme is also the willingness of teenagers to convey personal information to their friends online. When teens have a willingness to open themselves, then they no longer feel awkward to discuss various things with their friends online, so the topic of conversation becomes more flexible/broad and deep.

"Kalau menurut saya sih untuk masalah pribadi harus dijaga sih untuk orang lain. Kalau masalah pribadi itu urusannya pribadi sendiri, gausah diumbarumbar ke orang lain. Menurut saya itu agak aneh juga karna walaupun udah deket kita pun ga bisa percaya pribadi kita gimana-gimana." (FR/1/M)

\section{Trust}

Trust depicts a teenager's belief in the truth of what his online friend has to say about his identity and other information and the belief that his friend will protect the privacy and information he provides by not spreading it to others so that he can be embarrassed or hurt.

"Kalo sama orang yang bisa saya percaya, lima lah, saya suka cerita, dia juga cerita ke saya, kalo curhat curhat gitu. Apa sih yang membuat mau berteman dengan dia? Ya karena dia juga terbuka di group, jadi kan kita juga kalo yang lain terbuka masa kita engga, dia juga bisa jaga rahasia jadi saya berani cerita" $(F R / 1 / S)$

\section{The Dynamic}

In online friendships, teens generally start their interactions by looking for similarities between them, such as similar interests or activities. It can lead to an interest in interacting mutually between them. People are more likely to participate in activities together with other people who have the same interests. By doing that, they will feel accepted validation of their attitudes and beliefs, which they find useful [25]. This perceived appreciation, in turn, will stimulate further interaction and form and maintain friendship [26]. Besides being influenced by similarity, the willingness to interact mutually with others is also influenced by the strength or weakness of the urge to relate to someone who owns that. That is because individuals who have high affiliate motivation tend to spend more time interacting with others than people with 
low affiliate motivation. Individuals who have high affiliate motivation tend to visit their friends more often, make more telephone calls, and write more letters than people who are low in affiliated motivation [27]. Of course, the characteristics of partners will also affect whether someone is willing to interact or not with someone.

When their willingness to interact with each other grows, individuals try to show a positive attitude towards others, so that when they feel comfortable in their interactions will encourage someone to do activities with others and share information. The amount and depth of information shared between them depend on their willingness to open up to their partners. Individuals who have self-disclosure have the characteristics of having the desire to express or open themselves, expressing weaknesses and weaknesses as evaluative, conveying the condition of the self following the perceived and able to convey things that are considered personal to him [28]. It shows that people with high self-disclosure will show more flexible sharing behavior because they will be able to convey various things, ranging from the ordinary to the personal, and self-disclosure is influenced by trust.

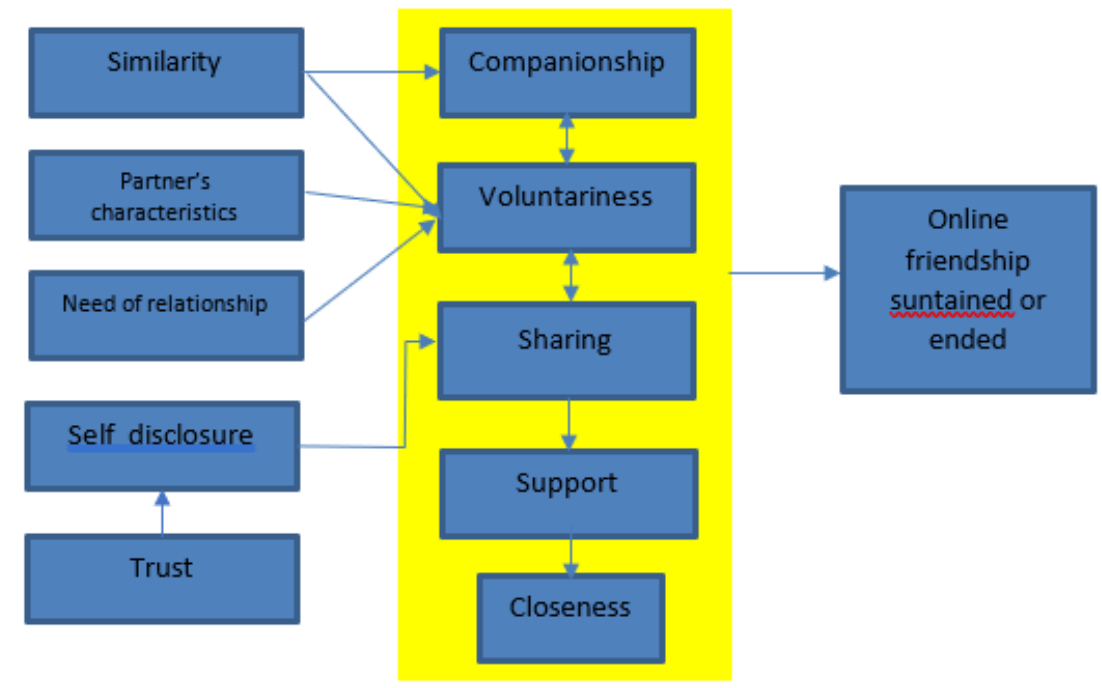

FIGURE 1. The dynamic of online friendships

When their willingness to interact with each other grows, individuals try to show a positive attitude towards others, so that when they feel comfortable in their interactions will encourage someone to do activities with others and share information. The amount and depth of information shared between them depend on their willingness to open up to their partners. Individuals who have self-disclosure have the characteristics of having the desire to express or open themselves, expressing weaknesses and weaknesses as evaluative, conveying the condition of the self following the perceived and able to convey things that are considered personal to him [29]. It shows that people with high self-disclosure will show more flexible sharing behavior because they will be able to convey various things, ranging from the ordinary to the personal. However, even though some teenagers have high self-disclosure, he still tries to be selective in sharing information with others, he will only share personal or privacy matters to people he already knows, because they are aware of the risks of danger in cyberspace if they carelessly share information about themselves. 
Sharing behavior accompanied by high self-disclosure can make people share their problems with their friends or vice versa. Thus it can stimulate the helping behavior of the sharing partner. If the sharing and helping behavior is well maintained, it can create closeness, so that online friendships will be adequately maintained. Conversely, if the dimensions or features are not well developed, it can cause the quality of online friendships can not develop well, even online friendships can end. The results of this study also show that in online friendships, people are very vulnerable to ending their relation when in trouble, especially when the two parties are not appropriately resolved. (Figure 1)

\section{CONCLUSIONS}

This research found that six dimensions can build online friendships, namely companionship, sharing, support, voluntariness, cautiousness and closeness. Five of the six dimensions are the same as the results of previous studies [22], and there is one additional dimension, namely closeness. This study also found four aspects that can affect the quality of online friendships, such as similarity, partner's characteristics, the motivation of affiliation, and self-disclosure. These factors affect the quality of online friendships, especially the dimensions of voluntariness, companionship, and sharing.

\section{REFERENCES}

[1] S. R. Hiltz and M. Turoff, The network nation: Human communication via computer, Revised. MIT Press, 1993.

[2] H. Rheingold, The virtual community: Homesteading on the electronic frontier, 2nd ed. MIT Press, 2000.

[3] B. Y. A. Lenhart et al., "Teens, Technology \& Friendships: Video games, social media and moble phones play an integral role in how teens meet and interact with friends.," Pew Res. Center's Internet Am. Life Proj., pp. 1-76, 2015.

[4] B. Fröding and M. Peterson, "Why virtual friendship is no genuine friendship," Ethics Inf. Technol., vol. 14, no. 3, pp. 201-207, Sep. 2012.

[5] D. Cocking and S. Matthews, "Unreal friends," Ethics Inf. Technol., vol. 2, pp. 223231, 2000.

[6] K. Y. A. McKenna, A. S. Green, and M. E. J. Gleason, "Relationship formation on the internet: What's the big attraction?," J. Soc. Issues, vol. 58, no. 1, pp. 9-31, Jan. 2002.

[7] W. Bülow and C. Felix, "On friendship between online equals," Philos. Technol., vol. 29, no. 1, pp. 21-34, Mar. 2016.

[8] A. Elder, "Excellent online friendships: an Aristotelian defense of social media," Ethics Inf. Technol., vol. 16, no. 4, pp. 287-297, 2014.

[9] D. K. S. Chan and G. H. L. Cheng, "A comparison of offline and online friendship qualities at different stages of relationship development," J. Soc. Pers. Relat., vol. 21, no. 3, pp. 305-320, 2004.

[10] M. L. Antheunis, P. M. Valkenburg, and J. Peter, "The quality of online, offline, and mixed-mode friendships among users of a social networking site," Cyberpsychology, vol. 6, no. 3, p. 6, 2012.

[11] G. H. Y. Chan and T. Wing Lo, "Do friendship and intimacy in virtual communications exist? An investigation of online friendship and intimacy in the context of hidden youth in Hong Kong," Rev. Cercet. si Interv. Soc., vol. 47, pp. 117$136,2014$. 
[12] A. N. Luknanto and A. F. Helmi, "Perbandingan kualitas antara pertemanan online dan pertemanan offline pada remaja," Universitas Gadjah Mada, 2015.

[13] G. H. L. Cheng, D. K. S. Chan, and P. Y. Tong, "Compositions and durations," CyberPsychology Behav., vol. 9, no. 1, pp. 14-21, 2006.

[14] J. B. Walther, "Interpersonal effects in computer-mediated interaction: A relational perspective," Communic. Res., vol. 19, no. 1, pp. 52-90, 1992.

[15] J. B. Walther, "Social information processing theory," in The international encyclopedia of interpersonal communication, 1st ed., C. R. Berger and M. E. Roloff, Eds. John Wiley \& Sons, Inc, 2016, pp. 1-13.

[16] J. B. Walther and M. R. Parks, "Cues filtered out, cues filtered in," in Handbook of interpersonal communication, 3rd ed., M. L. Knapp and J. A. Daly, Eds. SAGE Publications, 2002, pp. 529-563.

[17] Y. J. Liang and J. B. Walther, "Computer mediated communication," Int. Encycl. Soc. Behav. Sci. Second Ed., pp. 504-509, 2015.

[18] A. Ramirez and S. Zhang, "When online meets offline: The effect of modality switching on relational communication," Commun. Monogr., vol. 74, no. 3, pp. 287310, 2007.

[19] R. H. Lengel and R. L. Daft, “An exploratory analysis of the relationship between media richness and managerial information processing," 1984.

[20] J. C. Yau and S. M. Reich, "Are the Qualities of Adolescents' Offline Friendships Present in Digital Interactions?," Adolesc. Res. Rev., vol. 3, no. 3, pp. 339-355, Sep. 2018.

[21] K. Verswijvel, W. Heirman, K. Hardies, and M. Walrave, "Designing and validating the friendship quality on social network sites questionnaire," Comput. Human Behav., vol. 86, pp. 289-298, 2018.

[22] A. F. Helmi, W. Widhiarso, and A. N. Husna, "The development of online friendship scale,” Int. J. Cyber Behav. Psychol. Learn., vol. 7, no. 4, pp. 12-25, Oct. 2017.

[23] G. Mesch and I. Talmud, "The quality of online and offline relationships: The role of multiplexity and duration of social relationships," Inf. Soc., vol. 22, no. 3, pp. 137$148,2006$.

[24] J. Corbin and A. Strauss, Basics of qualitative research: Techniques and procedures for developing grounded theory, 3rd ed. Sage Publications, Inc, 2008.

[25] M. J. Mendelson and F. E. Aboud, "Measuring friendship quality in late adolescents and young adults: McGill Friendship Questionnaires.," Can. J. Behav. Sci. / Rev. Can. des Sci. du Comport., vol. 31, no. 2, pp. 130-132, 1999.

[26] R. Reagans, "Preferences, identity, and competition: Predicting tie strength from demographic data," Manage. Sci., vol. 51, no. 9, pp. 1374-1383, Sep. 2005.

[27] R. Koestner and D. C. Mcclelland, "The affiliation motive," in Motivation and personality: Handbook of thematic content analysis, 1st ed., C. P. Smith, Ed. New York, NY, US: Cambridge University Press, 1992.

[28] L. R. Wheeless and J. Grotz, "Conceptualization and measurement of reported selfdisclosure," Hum. Commun. Res., vol. 2, no. 4, pp. 338-346, Jun. 1976. 